\title{
Universities and enhancement of English as a second language in Tanzanian secondary schools
}

\author{
Mohamed, Hashim Issa $\<$ \\ Sokoine University of Agriculture, Tanzania (mohhashim@gmail.com) \\ Received: 4 November 2020 \\ Available Online: 30 January 2021

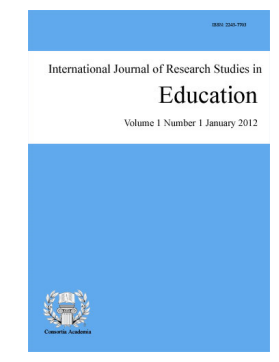

Accepted: 23 January 2021

ISSN: 2243-7703 Online ISSN: 2243-7711

OPEN ACCESS

\section{Abstract}

It has become apparent that students arrive at the university with insufficient English language proficiency; this is despite that English is the medium of instruction at secondary schools and universities in Tanzania. Thus, considerable amount of time is wasted by students grappling with the language of instruction instead of learning their other subjects. Poor abilities in English as a Second Language (ESL) undermine university efforts of producing competitive graduates in the regional job market. If this trend continues, Tanzania's goal of training requisite manpower for sustainable use of Science, Technology, and Innovation (STI) in development will be difficult. There is little evidence that universities have concrete measures to address students' ESL problems in secondary schools, which are the catchment areas. The study explored ways in which universities in Tanzania could intervene in strengthening students' ESL in secondary schools. The study followed a qualitative research design to collect data using Key informants' interviews from teachers and lecturers; Focus group discussions with teachers, and Open-ended questionnaires to university students, and classroom observation in both secondary schools and universities. The findings show that universities connect with secondary schools only during field practical training (FPT) of university student teachers. The study recommends that universities could intervene by providing in-service training opportunities to secondary teachers on new ideas on classroom ESL pedagogies; collaboration in research and practice (developing T/L materials), having common forums in addressing ELT in Tanzania with the aim of inputting what is happening in secondary schools into university practice and vice versa.

Keywords: collaboration; strengthening; intervention; research; ESL 


\section{Universities and enhancement of English as a second language in Tanzanian secondary schools}

\section{Introduction}

The British introduced English in Tanzania as an instrument of governance under colonial administration. At the post First Imperialist War in 1919, Tanganyika, now Tanzania was taken over by the British from the former rulers, the Germans. The British rulers who arrived in the Tanganyika territory in 1925, continued to maintain Kiswahili as a medium of communication in education (especially in the first five years of Primary education, as did the Germans). Besides, the British as their colonial mandate to Tanganyika created an official standard Kiswahili (Rubagumya, 1990; Blommaert, 2004). Concurrently, the British introduced English language as a school subject from primary three and made it the medium of education from primary five and above. In this respect, the British replaced Kiswahili with English as a medium of education in these levels, but allowed Kiswahili to be offered as a subject. In the outside school community, English became the official language in new communicative domains such as administration, legislature, and the judiciary.

The trend was reversed at postcolonial period, when political leaders under the Tanganyika African National Union (TANU) party became engaged in Kiswahili promotion initiatives, under a bigger national renascence programme featuring liberation, nationalism, and cultural identity. These initiatives were made on the understanding that any success for the struggle for Tanganyika in political and economic independence would partly hinge on the use of Kiswahili, which was envisaged to become a tool of social cohesion, revolution, and national unity. Therefore, from post-independence period, the emphasis has been on enhancing Kiswahili to enable it cater for all societal communicative needs of all Tanzanians. The initiatives led to the establishment of the Baraza la Kiswahili la Taifa (the Kiswahili Council of Tanzania), which was mandated to implement the Kiswahili promotion agenda in the country. The body has been instrumental in developing and backstopping programs for the implementation of the 1997 cultural and education policy.

Language reform in Tanzania was an integral part of the implementation of the major social economic policy, which was termed Ujamaa (African socialism). Ujamaa, which was officially proclaimed under the Arusha Declaration (AD) in Arusha in 1967, was aimed at spelling out the Tanzania's social, political, and economic future. The Ujamaa policy, which essentially emphasized on egalitarian principles, had adjunct policies as implementation strategies of AD and especially of transforming Tanzania into an egalitarian society. Among the notables of the agents of the mother policy, include Ujamaa Vijijini (villagesation program) of October 1967, (see Nyerere, 1967) and Education for Self-Reliance (ESR).

These policy reforms have had significant influence on socio-economic profile of Tanzania as a whole and on language policy and planning in particular. As for the former, the use of Kiswahili, which was accessible to the majority of people, was considered as appropriate in achieving socio economic transformation envisioned in the AD. Kiswahili was also considered as the most appropriate tool in unifying the Tanzanian population because of its being loyalty neutral, inter-ethnic language; and unlike English, Kiswahili is an indigenous language (see Paulston, 1994).

In the education sector, the Education for Self-Reliance (ESR) was instrumental in the implementation of the Arusha declaration. The ESR was aimed at replacing the colonial form of education, which was in all its intents, elitist and by far removed from the basic social and egalitarian principles enshrined in the AD. The reforms were aimed at responding to "...people's clamour “ ... for greater access to education and other social services denied them during the colonial education" (Roy-Campbell \& Qorro, 1997, p. 1). One of the reforms was the medium of education. This saw Kiswahili assuming a dominant role in the primary education as the medium of instruction (MoI) and English retaining its earlier status as a school subject. In post-primary education, however, English

84 Consortia Academia Publishing (A partner of Network of Professional Researchers and Educators) 
Universities and enhancement of English as a second language in Tanzanian secondary schools

and Kiswahili continued; the former as a medium and the latter as a school subject. English also became a de facto medium of education and Kiswahili continued to be offered as a taught course in higher education.

The selection and development of an indigenous language, Kiswahili, for particular communicative roles have enabled Tanzania to make significant strides in her trajectory towards the restoration of cultural independence and national pride lost during colonial rule. Further, the "state's attempt of generalizing Kiswahili at almost all levels of social and economic domains in Tanzania, was and still is, .. " a huge success" (see Blommaert, 2004). "However, similar success was not realized in the ideological hegemony towards language policy and planning in Tanzania" (see Mohamed, 2006, P.7) firstly, the egalitarian principles through which Kiswahili was distributed did not guarantee socio-economic equality enshrined in Ujamaa policy. Variation in social economic status among Tanzanians is more evident now than ever before.

Secondly, English is still dominant in the Tanzanian socio-economic domain and is perceived by many Tanzanian people as, among other things, a 'Highway to success,' 'a Gateway to social rewards', and most importantly, as an 'empowerment language' (Neke, 2003, p. 140). However, the state's efforts of privileging English have not been rewarding in the education sector. Indeed, English has become a barrier among many Tanzanians, especially from poor social economic background, of accessing higher education. However, this was one of the reasons that caused Tanzania to implement the language policy reforms cited in the foregoing sections.

Therefore, in spite of the government's efforts, students' ESL academic incompetence continued to stimulate discussions on the pedagogy of secondary schools and above in Tanzania. Furthermore, volumes of empirical literature have continued to document communication problems entrenched in the provision of knowledge and skills at secondary school level and above in the Tanzania education system. The discussions have often cited language policy in education as a culprit by presumably assuming a wrong footing. As cited above, the language policy in education is such that, with the exception of English medium primary schools, students undergo instruction in Kiswahili for seven years of primary education and then switch to English at secondary school. This orientation is considered as disruptive for students whose exposure to education has been in the medium of Kiswahili throughout their prime learning time in primary school. In this respect, Roy-Campbell and Qorro (1997, p. 2) observe, "It was generally taken for granted that after initial education in the vernacular, the child was ready to begin education in the foreign language."

In the Tanzanian classroom, considerable amount of time is wasted by students grappling with the language of instruction instead of learning their other subjects (see Mohamed, 2006, p. 10). In this realization, universities have devised a mechanism of addressing students' ESL weaknesses through English and academic communication courses. However, there is little evidence whether universities have taken similar measures to address students' ESL problems in secondary schools, which are the catchment areas for university students. As a result, English and communication incompetency, which students bring into universities inevitably, becomes a barrier for students' attainment of knowledge and skills required at the university. Thus, language barrier effectively becomes a barrier to knowledge, skills, and to all other competencies students need to attain at the university. Such incompetency also makes university efforts of designing remedial English proficiency programs fail to achieve the desired results (see for example, Komba \& Mohamed, 2016; Nyinondi et al., 2016). If this trend continues, Tanzania's goal of training requisite manpower for sustainable use of Science, Technology, and Innovation (STI) in development will be difficult to realize.

In this regard, this study is an attempt of investigating ways in which universities in Tanzania could be involved in enhancing students' ESL abilities in secondary schools. To understand the relevance of the current study, it is instructive to look briefly at some of the arguments that prompted the current research. One of the arguments is that when students join the universities, they bring with them background knowledge, including poor language abilities (Mohamed, 2006; Msuya, 2010), which severely inhibit students' learning of other subjects. Studies found that ability in language, in this case, English language, has a strong influence on students' performance in other subjects. For example, Bassey and Kamai (2016) in a study on the influence of English in 
the performance of science subjects in central and South Africa found that English has influenced performance in such subjects as Biology. These findings imply that strengthening students' abilities in English language will inevitably lead to the strengthening of students' knowledge acquisition in other subjects.

Another aspect, which prompted the current study, is the seemingly disconnection between what secondary schools are doing and what universities are doing in terms of the teaching of English subject and or language courses. This phenomenon is multilayered and it begins with the implementation of changes often made in secondary school syllabuses. For example, the recent changes in secondary school syllabus in 2005 in all subjects including English were meant to shift the focus of course delivery first from form to function and later from function to competence-based learning in secondary schools. However, there is little evidence that suggests that universities also revised their curriculum for English language courses to reflect the shift of focus that occurred in the secondary school English syllabus. The implication here is that whatever changes are made in secondary school syllabus do not have any far-reaching implication, outside the secondary school education system. And that, whatever good language learning to which students are exposed in secondary schools is unlikely to be enhanced at post-secondary school education including universities. And when such students enrol at universities as student teachers of English, they are unlikely to benefit from the foundation of competency-based learning they had acquired at Secondary School as students. This implies that universities will produce teachers who are not equipped with the skills of implementing curriculum changes in secondary school syllabuses.

As implied earlier, the changes in the syllabuses of Forms 1 to 4 , if implemented properly are capable of producing students who have the language competence that is required at the university. However, studies (MoEVT, 2011; ESRF, 2014)) revealed that teachers face two problems with the current syllabus; first, it is difficult for them to interpret the syllabus, and secondly, they lack the competency in teaching some of the concepts especially speaking and listening. This brings us to another equally important argument, that teachers in secondary schools implement changes, which are not clearly understood even by them. It is against this background that the current study seeks to investigate ways in which universities can contribute to the enhancement of ESL in secondary schools. This study is premised on the ground that universities are well resourced and have the capacity to interpret the changes in the secondary school syllabus and to make what appears difficult simple. This was envisaged to enhance ESL among students in secondary schools.

\subsection{Significance of the study}

It is globally acknowledged that school and university collaboration has continued to attract research interest in various collaborative platforms. It is worth noting however that much research on university -school collaboration focused on how to initiate strong connections between schools and universities in teacher education particularly on matters related to teachers' professional development. A study by Jialong et al. (2017) looked at Cooperation between universities and primary and secondary schools -Investigation on Teachers' Participation. A study by McLaughlin and Black-Hawkins (2004) on A Schools-University Research Partnership understandings, models and complexities intended to explore, as they put it, necessary conditions for useful practice-based research within individual schools, across schools and between schools and the university.. Specifically, their study looked at partnership on the development of practice-based research within and across schools and between schools and universities.

Sharon and Esther (2012) on their study on School-University Partnership: challenges and visions in the new decade attempted to synthesize the existing literature to understand trends of school-university partnerships in Hong Kong. Undoubtedly, researches in the initiatives of establishing school university collaboration have recorded significant transformation at both university and school levels, in leveling theory and practice gap (see Baumfield \& Butterworth, 2007; Kershner, Pedder, \& Doddington, 2012; Kruse, 2011), facilitating the development of teacher identity, contributing to teacher socialization (Kruse, 2011 in Brady, 2002) and promoting the learning of preservice teachers, school students, lecturers, and teachers (Allen et al., 2013 in Brady,

86 Consortia Academia Publishing (A partner of Network of Professional Researchers and Educators) 
2002). Such achievements bear witness that school university collaboration is not only important but also highly needed in the modern era where, as Sharon and Esther (2012) put it, 'The traditional view of university as a place for one-off training is now considered outdated .[1] Instead, a strong focus on lifelong learning urges teachers, educators and academics to re-conceptualize the ways education can be delivered (p. 38) and especially owing to the growing consensus that 'strong professional learning communities can foster teacher learning and instructional improvement’ (Borko, 2004, p. 6)

These studies therefore despite their huge interest in school university collaboration show little evidence to indicate that they focused on school university collaboration in terms of universities taking a leading role in enhancing the teaching of English as a Second Language in Secondary Schools, which is the focus of the current study. Similarly, collaboration studies have so far concentrated on school university partnerships in developed economies in the north particularly Europe, Asia and Far East Asia, Australia, and the Americas, there is limited evidence of similar studies in developing countries in Africa and Tanzania in particular. Studies on school university partnership in Africa include Mutemeri and Chetty (2011), Silbert et al. (2015), and Myende and Chikoko (2017) whose focus have been similar to the focus of studies in the global north where student teachers and teachers development have been at the core of the research interests, and not on university enhancement of English as a second language in secondary schools which is focused in the current study. In the Tanzanian context, studies on school university partnership have been scarce. In this respect, a study by Mgaiwa and Poncian (2016) looked at private public partnership commonly abbreviated as PPPs in higher education as a proxy of enabling public and private sectors share the costs and risks of education provision. This study did not even focus on school university partnership. Other partnership studies in Tanzania had such a remote connection with the current study that it was deemed unnecessary to cite them here. These observations make the current study have a unique contribution to the understanding of the nuances of school university collaboration especially in the enhancement of English as a second language in secondary schools in Tanzania.

\section{Methodology}

The study followed a qualitative research design to collect data using Key informants' interviews from secondary school teachers and university lecturers, secondary school inspectors, quality assurance executives, Undergraduate Studies Director at the university under study, headmasters of secondary schools involved in the study, Education officials in the Local Government (School Inspectors) in Tanzania. Because of their busy schedule, all these key informants' responded to interview questions through monkey surveys complemented with telephone conversations.

Focus group discussions for university lecturer and secondary school teachers were used as a way of triangulation, Open-ended questionnaire and oral interviews were administered to university lecturers and secondary school teachers. These tools were intended to solicit views from the respondents on pedagogical practices in ESL learning in secondary school vis-à-vis those occurring at universities. Documentary review in the form of reviewing literature in similar studies was conducted to gauge research gap and suitable models, which could be adopted for school university partnership in the Tanzanian context.

Overall, data were analyzed using content analysis; this was preceded with data processing where the data were filtered to remove irrelevant information, and unnecessary repetitions, followed by data coding. Specifically however, approaches proposed by Saldana (2014) Thinking Qualitatively Methods of Mind were followed. On his seminar work, Thinking Qualitatively, Saldana reveals how the researcher's mind thinks heuristically to transcend the descriptive and develop "high deep" insights about the human condition (Saldana, 2014) and extends to thinking analytically, realistically, symbolically, ethically, multidisciplinary, artistically, summarily, interpretively, and narratively which helped in data interpretation in the current study.

Data collection instruments were pretested by administering key interview guide questions to colleagues in the Department to make sure that they elicited the intended information as accurately as possible to ensure 
reliability and validity. Accordingly, the responses were examined, discrepancies rectified, and incomprehensible items clarified.

The study adhered to all ethical issues including seeking for permission from the Ethics Research Committee, and for introduction letters to seek for audience with all key informants. Consent was sought from key informants and other participants in the study, all of whom were informed of the purpose of the study, dissemination of findings, confidentiality, and on their willingness to participate. In other words, their freedom to drop at any stage of the research unconditionally was guaranteed.

\section{Findings and discussion}

\subsection{Findings}

The findings of the study from the four data collection methods, which are presented, in the methodology section were synthesized into two categories, namely confirmation of university involvement in enhancing ESL in secondary schools. Second, areas in which university can be involved in the ESL enhancement in secondary schools.

\section{Is there a need for university involvement?}

With regards to university involvement, findings revealed three contesting opinions; on the one hand, some instructors during FDGs were of the opinion that universities have no role to play in secondary school issues. As one member was heard saying

The issues of secondary schools should be the concerns of National Examination Councils, LGA

(Local Government Authority), TEA (Tanzania Education Authority) (and the Ministry of

Education., 'so where are the universities, here? It is not our concern' (FGDs, instructors, 2019).

Secondly, there are those who believe that only universities with education programs should be involved with secondary school affairs. In my college, we don't offer education courses, so I don't see where universities come in? Similarly, another respondent had this to say, 'If there is involvement, maybe it should involve specific faculties or departments' (FGDs-University lecturer, 2019).

The third category comprises those who believe that there is a need for university involvement in enhancing secondary school education performance. One member said,

'Universities' involvement in secondary schools is important; this is where we get our students. If students are poorly prepared, we end up getting poor students (Key informant-University lecturer, 2019).

This finding is congruent with the findings from secondary school teachers, which show that universities' involvement in secondary school performance in ESL is important. For these respondents, university involvement is perceived in terms of assistance in the in-service training, resource mobilization such as teaching and learning materials, and having the necessary influence on policy-making bodies, such as LGAs, the Ministry of Education and Vocational Training and Technology and other Education Authorities, in terms of improving teachers' welfare and professional skills. As one of the respondents observed,

You know university lecturers are very close to decision-makers, so if we partner with them they influence those decision-makers to consider secondary schools in terms of resources and motivation (FGDs, sec. schoolteachers, 2019). 


\section{What are the areas for university involvement?}

The areas earmarked for collaborative partnerships include training, research, university school visit, school events, resource utilization, contractual relationship legitimation, quality assurance, resource mobilization, and monitoring and evaluation. These findings from the study and literature are summarized in Table 1 and these areas are explained in detail in the discussion section.

\section{Table 1}

Areas of intervention in enhancing ESL in secondary schools

\begin{tabular}{|c|c|c|}
\hline $\mathrm{S} / \mathrm{N}$ & Areas/Key features & Areas of intervention activities \\
\hline 1 & Training & $\begin{array}{l}\text { Capacity building through short term training, seminars, workshops, conferences } \\
\text { on language teaching methodologies, that is, subject matter, technology, and } \\
\text { information management systems. }\end{array}$ \\
\hline 2 & Research & Language learning and training, curriculum development and implementation. \\
\hline 3 & University school-visits & $\begin{array}{l}\text { Creating awareness of what is happening on either side of the collaboration. } \\
\text { Provide intrinsic motivation among students and teachers in building capacity in } \\
\text { their areas of specialization. } \\
\text { Assessment of usage and availability of English language resources } \\
\text { Identify areas of improvement of such resources to enhance English language } \\
\text { learning. } \\
\text { Exploring areas of difficulties secondary school face in language learning and } \\
\text { addressing challenges whenever they arise. } \\
\text { Secondary teachers touring language units or departments at universities to see } \\
\text { how language is taught, or how certain resources are used to facilitate language } \\
\text { learning and the like }\end{array}$ \\
\hline 4 & School Events & $\begin{array}{l}\text { Involving get-together parties, exhibitions, or public lectures by key speakers } \\
\text { giving inspirational speeches or testimonies of the benefits accrued from a } \\
\text { particular English language approach as teachers or learners. }\end{array}$ \\
\hline 5 & Resources utilization & $\begin{array}{l}\text { Instructors used in secondary schools as volunteer teachers to support schools in } \\
\text { the teaching of specific language areas that may prove difficult. } \\
\text { University student teachers used in secondary schools as teaching practice centres } \\
\text { University student teachers used in secondary schools to help out in raising the } \\
\text { level of academic achievement in specific language areas and raising the interest of } \\
\text { secondary school students to attend university. } \\
\text { Secondary schools using language resources available in the university Units or } \\
\text { Departments. }\end{array}$ \\
\hline 6 & Contractual relationship & Legalistic, areas of responsibility finance-led \\
\hline 7 & Legitimation & Commitment to value of collaboration \\
\hline 8 & Quality assurance & $\begin{array}{l}\text { All collaborative partners have a role to play in quality assurance, and ensuring that } \\
\text { the objectives of collaborative partnerships are achieved. }\end{array}$ \\
\hline 9 & Resource mobilization & $\begin{array}{l}\text { Many of the collaborative activities may have an implication on the resource, and } \\
\text { therefore resource mobilization is crucial for the sustainability of the collaboration }\end{array}$ \\
\hline 10 & Monitoring and evaluation & $\begin{array}{l}\text { As indicated earlier the collaborative activities should in the end result in the } \\
\text { desired impact i.e. Strengthening of students' ESL in schools. To ensure that such } \\
\text { objectives are achieved monitoring and evaluation is essential. }\end{array}$ \\
\hline
\end{tabular}

Source. Field data, 2019.

\subsection{Discussion of findings}

In the study findings, there are some emerging issues, which can be categorized into four thematic areas, namely, Cultural and institutional barriers to university involvement in school collaboration, Misconception of what university school linkages is all about, the need for university school collaborative relationship, and areas for university -school linkages. Each of these areas is discussed below a follows.

\section{Cultural and institutional barriers to university involvement in school collaboration}

To begin with, the question as to whether or not there is a need for collaboration, some instructors commented that universities do not have a role to play. These instructors response has not come by accident; it is historically and culturally biased. 
Tanzanian education comprises secondary schools, colleges and universities, thus, since education works as a system, the link between these institutions is paramount. In Tanzania, however, this crucial part of education in relation to university and school collaboration has been neglected. For years, primary and secondary school education has been influenced by Ujamaa or African socialism of Nyerere, which insisted on Education for Self-Reliance policy (ESR). Mwalimu Nyerere aimed to liberate education that had some colonial elements soon after independence. According to Nyerere (1973 cited in Nyirenda \& Ishumi, 2002, p. 157), "the purpose of education, is to provide school leavers with the knowledge, skills and attitudes relevant to the development of the learners' own community." This was the basis for the establishment of ESR, and which was aimed at making secondary education complete by itself, instead of being a preparing ground for higher education.

Thus, the education system was set in such a way that very few people could reach the tertiary level. Many school leavers were prepared to be independent in terms of knowledge, skills, and practice. This tradition has been in practice for generations regardless of the paradigm shift in the education system. From this time, secondary education began to have specialization in such areas as agriculture, commerce, technical education, and the like. In other words, we had and still have agricultural, commercial, technical secondary schools and so on. This orientation is however changing rapidly, where we are witnessing the same discipline biased secondary schools becoming preparatory grounds for potential university entrants. As a result, universities are overwhelmed by students due to the change in education orientation, many secondary schools have been established, and a good number of students are enrolled. The major focus was/is to make sure all these students enter universities. Further, the said entrants are said to be weak in terms of comprehension during the learning and teaching process; and they cannot use English eloquently. This is what is termed in some literature as historically based cultural and institutional barriers (Guimón, 2013).

\section{The misconception of what university school linkages is all about}

From the findings, it was observed that university-school linkages should only apply to universities with education programmes. This belief is guided by the reality that student teachers at university have to take field practical training (FPT) in secondary schools. To them, this is the only area where a university can play a role in secondary school performance. This belief is problematic for two reasons first, field practical is not aimed at strengthening performance including students' abilities in ESL, rather it is an industrial training, which is done occasionally, and it may involve universities or any other industry where such universities can send their students for industrial training. Therefore, it is neither a linkage nor collaboration. It also lacks permanency, in that, every year universities and student teachers need to solicit placement for such an activity, and some schools may not receive same student teachers.

From this perspective, it follows therefore that university-school linkages and collaboration are not well rooted in the institutional culture of many universities in Tanzania. In addition, as Guimón (2013, p. 3) observes, first, the collaboration which exits 'often involves universities and industry' and, secondly these collaborations have 'tended to be more informal and to focus on the firms' recruitment of university graduates for staffing, internships, and consulting.' This is analogous to the relationship that exists between universities and schools when it comes to field practical training for student teachers at university.

\section{The need for university school collaborative relationship}

There is little evidence of the existence of formal collaborations between universities and schools. However, experience shows that collaborations between universities and schools do exist in some places at an informal level involving individual staffs in these universities conducting motivational activities in the schools concerned. However, elsewhere research has shown that

The widespread adoption of university-school partnerships cannot be left to individual initiative. No finding is clearer in this study than the need for active contributions by school systems and governments. Encouraging policy will be one contribution but, alone, the policy will be

90 Consortia Academia Publishing (A partner of Network of Professional Researchers and Educators) 
Universities and enhancement of English as a second language in Tanzanian secondary schools

insufficient to ensure that local partnership teams are able to sustain their work (Kruger et al., 2009 , p. 45).

University lecturers are the think tanks of the nation, when lecturers are not involved in educational matters, regardless of the level, the outcome is what we are witnessing in secondary school today where problems in both language and knowledge acquisition are frequent and disturbing. Therefore, partnerships between universities and schools would provide opportunities for universities to go beyond research and pilot studies to the development of the authentic and effective implementation of their findings and recommendations (Cf. Kruger et al., 2009). In addition, the analogy of university school linkages is that of universities and industry which is provided by Guimón (2013) who argues that

"The benefits of university-industry linkages are wide-reaching: they can help coordinate Research and Development $(R \& D)$ agendas and avoid duplications, stimulate additional private $R \& D$ investment (additionality effect), and exploit synergies and complementarities of scientific and technological capabilities" (2013, p. 1).

The same argument applies to University-Secondary school -LGA linkages. The linkages between these three nodes may, in one way or the other, improve the teaching of various courses/subjects including English. For instance, a university as a research institute may propose ways of overcoming different challenges that arise in the teaching and learning of English. Therefore, at this time, where everyone aims at gaining a university certificate, the link between universities and secondary school is paramount and therefore exploring such a link is inevitable.

\section{Areas for university -school linkages}

According to the study findings, the areas of university involvement are as indicated in Table 1 . These are discussed below as follows:

Training - Most secondary school teachers were on the opinion that universities should intervene in providing capacity building through short-term training, seminars, workshops, and conferences on language teaching methodologies, that is, subject matter, technology, and information management systems. These are the prime commodities in the education system today, where there is a paradigm shift involving the use of science and technology in teaching and training. Universities are reputed to be reservoirs of human resource with the skills required in the context of the use of science and technology in language teaching. Similarly, universities are more or less equipped with science and technology such as language resource centres. On this aspect, one respondent suggested that universities should be involved by:

Practically working on the competence of teacher trainees who finally become teachers for the subject. Speaking skills is not thoroughly emphasized during training and assessment. Ask yourself at which level of English language learning, oral examinations are done? (Questionnaire University Lecturer, 2019)

Research - In the area of research, it was envisaged that universities have the capacity and skills in research and methods of analysis. On the other hand, secondary schools can be good sources of information on the areas, which are researched on. The areas that can be involved in collaborative research include language learning and training, curriculum development and implementation. On research, one participant said,

'Researching on curriculum and its implementation for its change and improvement is one of the things that can be done by universities and schools' (Interviews, university lecturer 2019)

Under this aspect, observation is made to teacher's ability to use language in teaching the language (performance). For instance, if the teacher makes grammatical errors, are these errors associated with other factors or with teacher's ability (Questionnaire, school teacher 2019) 
University - school visits - is a visit that is paid by either party with the aim of creating awareness on what is happening on the other side of the collaboration. This was envisaged to increase intrinsic motivation among students and teachers in building capacity in their areas of specialization. Some of the observations made from the questionnaires data were as follows

Paying regular visits to these secondary schools, observing what and how students learn English. Inviting secondary school teachers and students to observe what and how university students and teachers learn and teach respectively. It is through this experience where we can bring about a state of balance of the curriculum material and methodology between the two levels of education that is, university, and secondary (Questionnaire, university lecturer 2019)

Under university -school visit, excursion was also cited. This is a form of study visit, which either party can make to the other party to learn specific language learning objectives. This could entail secondary teachers touring language units or departments at universities to see how language is taught, or how certain resources are used to facilitate language learning and the like. Universities can also visit secondary schools to see what materials are available and how they are put to use, or rather to see how such resources could be improvised to aid language learning. This can also be a learning tour where instructors could be exposed to the kind of difficulties secondary school face in language learning.

School Events - This may involve get-together parties, exhibitions, or public lectures - involving key speakers who might be giving inspirational speeches or testimonies of the benefits accrued from a particular English language approach as teachers or learners. School events also provide an avenue where through get together, ESL in secondary schools can be enhanced. As Jacobs and Farrell (2003, p. 9) surmise, 'students learn via interacting with their environment, and the key features of that environment are the people with whom they come into contact' and according to Mohamed:

These include not just language teachers, but also teachers of content subjects, peers and where appropriate modal speakers of the target language who are available in the community. This implies that classrooms are the micro environments where languages can be learned, but these micro environments should be supported by the macro environment, the society which classrooms painstakingly try to reflect $(2018$, p. 4)

Resources utilization - University instructors during their free times or while on sabbaticals can be utilized in secondary schools as volunteer teachers to support schools in the teaching of specific language areas that may prove difficult. University student teachers can use these secondary schools as teaching practice centres on a regular basis as opposed to the current trend where universities connect with school when sending student teachers to these schools during field practice training only. University student teachers can also be utilized in secondary schools to help in raising the level of academic achievement in specific language areas and in raising the interest of secondary school students to attend university.

Similarly, secondary schools could benefit from language resources available in the university language Units or Departments. Universities have the potential of attracting funding for physical and financial resources, which can be invested in language resources centres and facilities. These may be useful facilities for secondary school students when allowed to have access to such resources for language learning purposes.

\subsection{Implication and recommendations}

Universities and schools collaborative partnership is not a new phenomenon. Studies, for example, Kruger et al. (2009), have shown that collaborative partnerships between universities and schools have been very successful in Australia in raising and maintaining good competency levels of secondary school teachers, as well as preparing such students for pursuing a university education.

92 Consortia Academia Publishing (A partner of Network of Professional Researchers and Educators) 
According to the authors in Australia, these partnerships are said to

have been successful in forging stronger links with schools, generating increased involvement of schools in (the) university's programs, enhancing the reflective engagement of pre-service teachers in the learning and teaching process and increasing the satisfaction of pre-service teachers and their commitment to the course ( Kruger et al., 2009, p. 45).

Partly as is the case with the teacher education system in Tanzania, in the case of Australia Victorian report (2005: cited in Kruger et al., 2009, p. 46), the following are the failings in schools that prompted universities-schools partnership. 'Two of the 'greatest barriers to achieving a better balance between theory and practice in teacher education, and thus to improving the suitability of current courses' are that teacher educators are out-of-touch with school classroom practices and that teachers are not asked to contribute to teacher education course design.

One of the drivers in this practice is the realization that teacher education and particularly secondary school education is a shared responsibility and that, the problems secondary school face regarding curriculum implementation are enormous for the schools alone to overcome. Thus, concerted efforts from all stakeholders are required to address these challenges. Universities being one of the key stakeholders of secondary education, it is crucial that they find a way in which they can work together with secondary schools to overcome these challenges.

ESL Enhancement Intervention Model - University involvement in secondary schools, according to the findings, was suggested to take into consideration two things, first, it should result in mutual benefit, and reciprocity, and therefore collaboration was considered as the ideal system. Secondly, in the case of Tanzania, this collaboration should involve three players, universities, schools, and Local Education Authorities (which are within Local Government Authorities (LGA). Universities and schools will be primary collaborators; however, for some of the collaborative activities to have legality and legitimation, Local Education Authorizes within LGA need to be involved. LGA is the government arm of these schools and are the ones involved in the monitoring and evaluation of school programs, as well as the provision of human and financial resources for school governance and administration.

From the research findings and literature scan, this study develops a model for the university-schools partnership that incorporates findings from the study summarized in Table 1, literature scan and recommendations for university-school partnership specifying key responsibilities of each collaborator (See Figure 1, and Table 2).

Figure 1. ESL enhancement intervention model

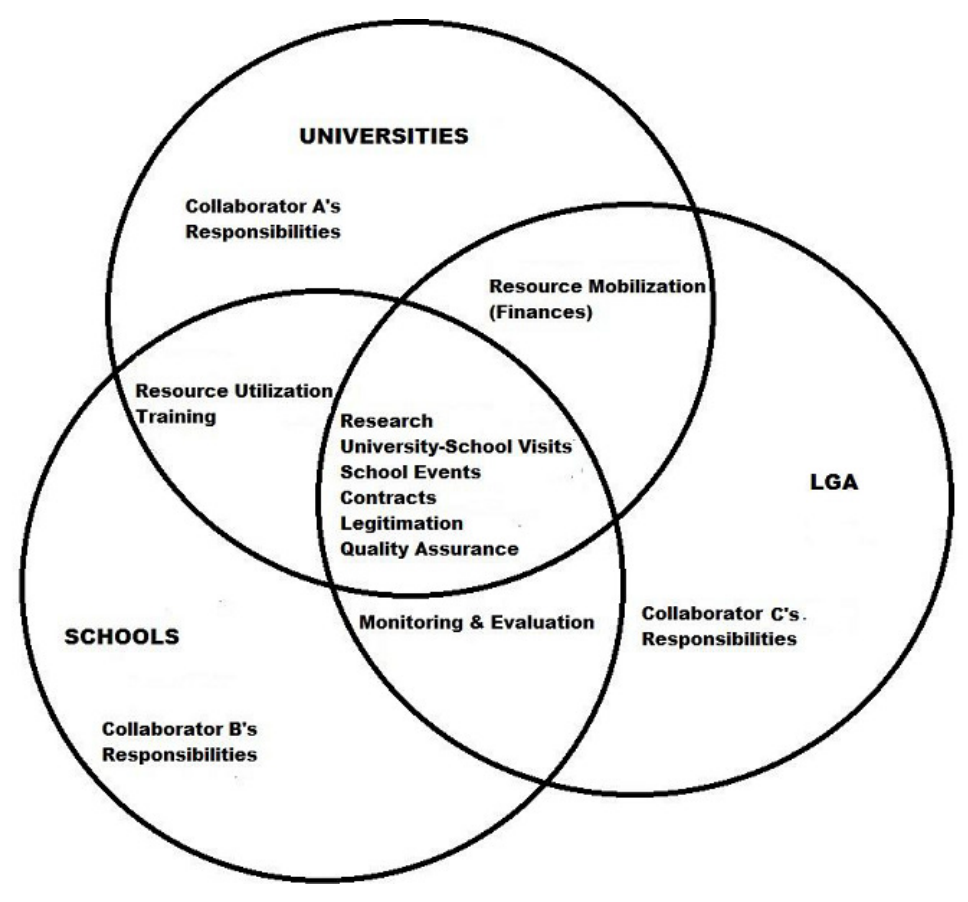


Responsibilities of each collaborator in the partnership - The diagram shows the ESL enhancement intervention relationship. The diagram involves three phenomena, first key collaborators in the partnership which are represented by the three circles in the diagram; second is areas of collaboration which are shown in the intersections, third key responsibilities of each collaborator represented in the area outside the intersections as Collaborator A (University), Collaborator B (Schools) and Collaborator C (LGA). These key responsibilities are listed in Table 2. The areas of partnership between and among members in the partnership also vary slightly depending on the responsibilities of each member in the collaboration. From the model, all members in the partnership will have some involvement in areas such as university school visits, which involves university visiting schools and schools visiting universities, contractual relationship, legitimation, schools events, and quality assurance. It should be realized that for this partnership to work, these areas of a partnership must involve all members in the partnership, because of the distinctive role each member will have to play. In some respects, it is the university and a school that must have a direct relationship; however, issues on legality and authorization make LGA become a key player in the partnership.

In this diagram, universities and schools have a direct relationship on such areas as training, research, and resource utilization for reasons explained in Table 1. Universities and LGA will have a direct relationship in resource mobilization such as finances, and LGA and schools will have a direct relationship in monitoring and evaluation. Responsibilities of each collaborator in the partnership are indicated in Table 2.

Table 2

Responsibilities of each collaborator in the partnership

\begin{tabular}{|c|c|c|c|}
\hline \multirow{2}{*}{ Key areas } & \multicolumn{3}{|c|}{ Collaborators' responsibilities } \\
\hline & Collaborator A (University) & Collaborator B (Schools) & LGA -educational leaders \\
\hline Training & $\begin{array}{l}\text { Facilitating teachers participation in } \\
\text { student learning of ESL } \\
\text { Assist teachers to articulate their } \\
\text { ESL knowledge and provide } \\
\text { guidance in pedagogical practice in } \\
\text { students' language learning } \\
\text { modelling exemplary practices of } \\
\text { teaching ESL } \\
\text { Connecting teachers' practice and } \\
\text { school student ESL earning needs on } \\
\text { the quality of the teaching and } \\
\text { learning process. }\end{array}$ & $\begin{array}{l}\text { Taking responsibility and enhancing } \\
\text { school student ESL learning about } \\
\text { student learning } \\
\text { Demonstrating professional } \\
\text { commitment through participation in } \\
\text { student ESL learning } \\
\text { Improving their practice through } \\
\text { involvement in students ESL learning } \\
\text { needs and in the model exemplary } \\
\text { practices }\end{array}$ & \\
\hline Research & $\begin{array}{l}\text { Conducting ESL needs analysis for } \\
\text { teachers and schools students }\end{array}$ & $\begin{array}{l}\text { Involvement } \\
\text { in students ESL learning needs }\end{array}$ & $\begin{array}{l}\text { Connecting partnership } \\
\text { activity with research } \\
\text { output }\end{array}$ \\
\hline $\begin{array}{l}\text { University } \\
\text { school-visits }\end{array}$ & $\begin{array}{l}\text { Identify areas of improvement of } \\
\text { such resources to enhance English } \\
\text { language learning } \\
\text { Creating awareness of what is } \\
\text { happening on either side of the } \\
\text { collaboration }\end{array}$ & $\begin{array}{l}\text { Involvement in the model exemplary } \\
\text { practices }\end{array}$ & $\begin{array}{l}\text { Liaison universities and } \\
\text { schools in identifying } \\
\text { needs and interests }\end{array}$ \\
\hline School Events & $\begin{array}{l}\text { Public lectures on inspirational } \\
\text { speeches or testimonies of the } \\
\text { benefits accrued from particular } \\
\text { English language approach as } \\
\text { teachers or learners }\end{array}$ & $\begin{array}{l}\text { Participation in seminars, lectures, } \\
\text { and public speeches }\end{array}$ & $\begin{array}{l}\text { Liaison universities and } \\
\text { schools in identifying } \\
\text { needs and interests }\end{array}$ \\
\hline $\begin{array}{l}\text { Resources } \\
\text { utilization }\end{array}$ & $\begin{array}{l}\text { Provides avenues for resource } \\
\text { utilization }\end{array}$ & $\begin{array}{l}\text { Utilization of resource avenues } \\
\text { Create avenues for university student } \\
\text { teachers to use secondary schools for } \\
\text { training in specific language areas }\end{array}$ & \\
\hline $\begin{array}{l}\text { Contractual } \\
\text { relationship }\end{array}$ & $\begin{array}{l}\text { Involvement in the discussions of on } \\
\text { the purpose and practice of } \\
\text { collaboration } \\
\text { Signing of MoU }\end{array}$ & $\begin{array}{l}\text { Involvement in the discussions of on } \\
\text { the purpose and practice of } \\
\text { collaboration } \\
\text { Signing of MoU }\end{array}$ & $\begin{array}{l}\text { Providing guidance in } \\
\text { discussions about the } \\
\text { purpose and practice of } \\
\text { collaboration } \\
\text { Supervising and or } \\
\text { guiding of MoU between } \\
\text { universities and schools }\end{array}$ \\
\hline
\end{tabular}


Universities and enhancement of English as a second language in Tanzanian secondary schools

\begin{tabular}{|c|c|c|c|}
\hline \multirow{2}{*}{ Key areas } & \multicolumn{3}{|c|}{ Collaborators' responsibilities } \\
\hline & Collaborator A (University) & Collaborator B (Schools) & LGA -educational leaders \\
\hline Legitimation & $\begin{array}{l}\text { Commitment to value of } \\
\text { collaboration identified in the MoU }\end{array}$ & $\begin{array}{l}\text { Commitment to value of collaboration } \\
\text { identified in the MoU }\end{array}$ & $\begin{array}{l}\text { Commitment to value of } \\
\text { collaboration identified in } \\
\text { the MoU }\end{array}$ \\
\hline $\begin{array}{l}\text { Quality } \\
\text { assurance }\end{array}$ & Provide professional advise & $\begin{array}{l}\text { Ensuring that school student ESL } \\
\text { learning is improved }\end{array}$ & $\begin{array}{l}\text { Ensuring a connection to } \\
\text { school priorities }\end{array}$ \\
\hline $\begin{array}{l}\text { Resource } \\
\text { mobilization }\end{array}$ & $\begin{array}{l}\text { Assist in writing project write-up for } \\
\text { soliciting funds for the smooth } \\
\text { running of the partnership }\end{array}$ & & $\begin{array}{l}\text { Funding research } \\
\text { activities }\end{array}$ \\
\hline $\begin{array}{l}\text { Monitoring } \\
\text { and evaluation }\end{array}$ & & $\begin{array}{l}\text { Taking responsibility and enhancing } \\
\text { school student ESL learning } \\
\text { Learning about student learning } \\
\text { demonstrating professional } \\
\text { commitment through participation in } \\
\text { student ESL learning }\end{array}$ & $\begin{array}{l}\text { Ensuring collaborative } \\
\text { activity in university } \\
\text { school partnership is } \\
\text { achieved } \\
\text { Committing to } \\
\text { partnerships over time }\end{array}$ \\
\hline
\end{tabular}

Source. Field data, 2019.

\section{Conclusion}

The current students' inability to master the language of education goes a long way in influencing negatively students' ability to access knowledge and skills, which they require to enable them, constitute a competent workforce for economic development. There is also likelihood for the existing trend to have a multiplier effect in the education quality chain where weaknesses in human capacity are transmitted from one generation to the next, as these graduates enter the education sector as instructors themselves.

In this respect, this study investigated ways in which universities can be involved in students' ESL enhancement in secondary schools. There is sufficient evidence that students joining universities are too weak in language abilities to benefit from university studies. Such a phenomenon also frustrates university efforts of raising students' language levels through language and academic communication courses designed at the university. We have seen elsewhere, for example, Australia, German, and Canada that such partnerships have been very successful "in forging stronger links with schools, generating increased involvement of schools in (the) university's program" (see Kruger et al., 2009, p.45). In the context of Tanzania, there is little evidence to suggest the existence of formal collaborations between universities and schools save for individual staff collaborating with secondary schools informally. However, as we have just seen, 'university-school partnerships cannot be left to individual initiatives and that there is a need for schools, government, and universities to partner for successful and sustainable ESL enhancement in secondary schools. Thus, study findings and literature have shown that there is a strong need for collaborative partnerships between universities and schools in addressing students' ESL problems in schools. The need for students to continue with higher education is also a result of the changing demands of the labour market that inevitably favour highly skilled workforce due to the advancement of science and technology. These new developments require these new university entrants to be well versed not only in their disciplinary subjects but also in language and communication for them to be better prepared for university education.

Acknowledgements - The author wishes to acknowledge all individuals that facilitated the production of this article. In this respect, a few individuals deserve to be mentioned Dr Nyinondi, Onesmo S. and Mhandeni, Abdulkarim Shaban, both from the Department of Language Studies of Sokoine University of Agriculture. I also wish to thank all participants who agreed to spare their time and share willingly their expertise and experience on the matters related to the study. Also thanks to Sokoine University of Agriculture for creating the enabling environment for carrying out the study. Lastly, the author wishes to declare that, there is no conflict of interest in the publication of this article. 


\section{References}

Bassey, A., \& Kamai, R. A. (2016). Writing biology, assessing biology: The nature and effects of variation in terminology. Terminology, 22(2), 201-222. https://doi.org/10.1075/term.22.2.03ant

Blommaert, J. (2004). Situating language rights: English and Swahili in Tanzania revisited. Linguistic Agency University of Duisburg.

Borko, H. (2004). Professional development and teacher learning: Mapping the terrain. Educational Researcher, 33(8), 3-15. https://doi.org/10.3102/0013189X033008003

Brady, L. (2002). School university partnerships: What do the schools want? Australian Journal of Teacher Education, 27(1). https://doi.org/10.14221/ajte.2002v27n1.1

Guimón, J. (2013). Promoting university-industry collaboration in developing countries. Innovation Policy Platform, OECD and World Bank. https://doi.org/10.13140/RG.2.1.5176.8488

Jacobs, G. M., \& Farrell, T. S. C. (2003). Understanding and implementing the CLT (communicative language teaching) paradigm. RELC Journal, 34(1), 5-30. https://doi.org/10.1177/003368820303400102

Jialong, L. Yuandong, Z., \& Yuanming, W. (2017). Cooperation between universities and primary and secondary schools: Investigation on teachers' participation. Advances in Economics, Business and Management Research, 29, 923-933. https://doi.org/10.2991/iemss-17.2017.180

Komba, S. C. \& Mohamed, H. I.(2016). Towards re-defining communication skills courses at Sokoine University of Agriculture: Lessons from selected African universities, International Journal of Research Studies in Language Learning, 5(5), 55-6. http://dx.doi.org/10.5861/ijrsll.2016.1478

Kruger, T., Davies, A. Eckersley B., Newell, F., \& Cherednichenko, B. (2009). Effective and sustainable university-school partnerships beyond determined efforts by inspired individual. Victoria University School of Education.

McLaughlin, C., \& Black-Hawkins, K. (2004). A schools-university research partnership: understandings, models and complexities. Journal of In-service Education, 30(2), 265-284. https://doi.org/10.1080/136745804002002

Mgaiwa, S. J., \& Poncian, J. (2016). Public-private partnership in higher education provision in Tanzania: implications for access to and quality of education. Bandung Journal of Global South, 3(6). https://doi.org/10.1186/s40728-016-0036-Z

Ministry of Education and Vocational Training. (2011). Educational sector development programs (USD): Education sector performance report 2010-2011.

Mohamed, H. I. (2006). Academic writing as social practice: A critical discourse analysis of student writing in higher education in Tanzania [Doctoral dissertation]. University of the Western Cape.

Mohamed, H. I. (2018). Paradigm Shift in Teaching Communication Skills Course in a Tanzanian University: An assessment and lessons for other universities. International Journal of Language and Linguistics, 6(5). https://doi.org/10.11648/j.ij11.20180605.15

Msuya, E. A. (2016). Language learning strategies by EFL secondary school learners in Tanzania: An exploratory account. Brazilian English Language Teaching Journal, 7(1), 94-108. https://doi.org/10.15448/2178-3640.2016.1.23414

Mutemeri, J.. \& Chetty, R. (2011). An examination of university-school partnerships in South Africa. South African Journal of Education, 31(4), 505-517. https://doi.org/10.15700/saje.v31n4a325

Myende, P., \& Chikoko, V. (2017). School-university partnership in a South African rural context: Possibilities for an asset-based approach. Journal of Human Ecology, 46(3), 249-259. https://doi.org/10.1080/09709274.2014.11906724

Neke, S. M. (2003). English in Tanzania: An anatomy of hegemony [Doctoral dissertation]. University of Gent. Nyerere, J. K. (1967). Education for self-reliance: A policy. Government Printers.

Nyinondi, O. S., Mhandeni, A. S., \& Mohamed, H. I. (2016). The use of communicative language teaching approach in the teaching of communication skills courses in Tanzanian universities. International Journal of Research Studies in Language Learning, 6(3), 89-99. https://doi.org/10.5861/ijrsll.2016.1528

Nyirenda, S. D., \& Ishumi, A. G. M. (2002). Philosophy of education: an introduction to concepts, principles, 
and practice. Dar es Salaam University Press.

Paulston, C. B. (1994). Linguistic minorities in multilingual settings: Implications for language policies. John Benjamini's Publishing Company

Rahimi, M., Zhang, L., \& Esfahani, N. (2016). Advocating school-university partnership for responsive teacher education and classroom-based curricula: evidence from teachers' cognitions about principles of curriculum design and their own roles. Australian Journal of Teacher Education, 41(12), 84-98. https://doi.org/10.14221/ajte.2016v41n12.6

Roy-Campbell, Z. M., \& Qorro, M. A. S. (1997). Language crisis in Tanzania: The myth of English versus education. Mkuki na Nyota.

Rubagumya, C. M. (1990). Language in education in Africa: A Tanzanian perspective. Multilingual Matters

Sharon S. N. Ng., \& Chan, E. Y. M. (2012). School-university partnership: Challenges and visions in the new decade. Global Studies of Childhood, 2(1), 38-56. https://doi.org/10.2304/gsch.2012.2.1.38

Silbert, C., \& Dornbrack, J. (2015). In schools, in community' - implementing a university-school partnership at the University of Cape Town. South African Journal of Higher Education, 29(3), 262-280. https://doi.org/10.20853/29-3-499

The Economic and Social Research Foundation. (2014). Declining quality of education: suggestions for arresting and revising the trend. ESRF. 
Mohamed, H. I.

98 Consortia Academia Publishing (A partner of Network of Professional Researchers and Educators) 